\title{
Efficacy of Boric Acid as a Treatment of Choice for Chronic Suppurative Otitis Media and Its Ototoxicity
}

\author{
Indri Adriztina ${ }^{1, *}$, Linda Irwani Adenin², Yuliani Mardiati Lubis² \\ 'Department of Otorhinolaryngology, Universitas Sumatera Utara, Medan, North Sumatera, Indonesia \\ ${ }^{2}$ Department of Otorhinolaryngology, H. Adam Malik General Hospital, Medan, North Sumatera, Indonesia
}

\begin{abstract}
Chronic suppurative otitis media (CSOM) is one of the most common chronic infectious diseases worldwide, especially affecting children. The patients or the parents of the affected children are often worried about the cost of medical visits, prescription medicines, or inconsistently effective medication. The complications of CSOM have been greatly reduced because of the development of antibiotics; however, the irrational use of antibiotics has led to the emergence of organisms resistant to the commonly used drugs. Owing to the increase in antibiotic resistance, the development of new treatments that will efficiently eradicate infectious microorganisms has become imperative. Boric acid solutions are effective in the treatment of CSOM because of their acidic effect. Various databases, such as the PubMed, The Cochrane Library, and SciELO, were searched for references related to the efficacy of boric acid in the treatment of mucosal CSOM, as well as its ototoxicity. The search revealed that boric acid is relatively effective in treating CSOM, especially at a high concentration. Boric acid in distilled water was found safe in animal studies. However, the ototoxicity of boric acid concentrations higher than $4 \%$ needs further evaluation, considering the effectivity of boric acid at high concentrations.
\end{abstract}

Keywords: Boric Acids; Suppurative Otitis Media; Biofilms; Toxicity

Received: July 6, 2017, Revised: August 5, 2017, Accepted: August 29, 2017

*Corresponding Author: Indri Adriztina https://orcid.org/0000-0003-0651-9594

Tel: +62-61-8211633, Fax: +62-61-8219411, E-mail: adriztina@yahoo.com 


\section{INTRODUCTION}

Chronic suppurative otitis media (CSOM) is characterized by persistent drainage from the middle ear associated with a perforated ear drum. Otoscopic examination of patients with CSOM reveals a red and inflamed middle ear with purulent discharge. CSOM is one of the most common chronic infectious diseases worldwide, affecting 65-330 million people especially in the developing countries. It usually develops in the early years of life but can persist during adulthood. A study in Indonesia found that 116 of the 7,005 children examined had CSOM. ${ }^{1,2)}$

CSOM is considered a multifactorial disease caused by a complex series of interactions between environmental, bacterial, host, and genetic risk factors. Although several factors play a role in the etiology of this disease, it is most commonly associated with the recurrent attack of otitis media during childhood. ${ }^{1,3)}$ If CSOM is not treated properly, it can result in many complications. The complications of CSOM can be classified as extracranial or intracranial, and occur more often in atticoantral-type CSOM than in tubotympanic CSOM. ${ }^{4-6)}$

The complications of CSOM have been greatly reduced because of the development of antibiotics. However, the irrational use of antibiotics has led to resistance in the organisms to the commonly used drugs. ${ }^{7)}$ Ear drops, either antibiotic or antiseptic, are often used in the treatment of CSOM. Many studies have reported good results with the use of aluminum acetate dissolved in water (Burow's solution) as an ear drop solution for CSOM or external otitis. It is effective because of its acidic and antiseptic characteristics. Unfortunately, Burow's solution was found to be ototoxic in animal studies. Boric acid solution, another antiseptic agent, is also effective because of its acidic characteristics. Moreover, its ototoxic effect has been assessed in many animal studies, albeit with inconsistent results. ${ }^{8,9)}$

Difficulties in treating the chronic infection can also be related to biofilm formation. Biofilms are involved in many chronic infections including multiple otorhinolaryngological diseases, such as chronic rhinosinusitis, cholesteatoma, adenotonsillitis, and chronic otitis me- dia. Biofilms are formed by many bacteria, including the most common causative organism of CSOM. These biofilms periodically release planktonic bacteria into the host, resulting in disease recurrence. Owing to a strong relationship between biofilms and infection chronicity, experts have been actively seeking antibiofilm agents to treat chronic infection, and one such agent is boric acid. Boric acid was found to have an antibiofilm effect against some bacterial strain cultures. ${ }^{10-13)} \mathrm{In}$ this review, we investigated the efficacy of boric acid in treating CSOM, as well as its ototoxicity.

\section{METHODOLOGY}

Various databases, such as the PubMed, The Cochrane Library, and SciELO, were searched to identify relevant articles. We focused our review on studies using boric acid for the treatment of mucosal CSOM and investigating its ototoxicity, with no publication date limitation. We searched using the term "BORIC ACID" AND OTITIS MEDIA OR CSOM OR OTITIS MEDIA SUPPURATIVE, and selected only articles on humans with mucosal CSOM without complication and surgical intervention, or in vitro analysis of bacteria causing CSOM. The search for articles on ototoxicity was performed using the terms BORIC ACID and OTOTOXIC. Publications in languages other than English and review articles were not included in this review.

\section{STUDY SELECTION}

A total of 24 articles were identified, from which 8 were removed as these were duplicates (Figure 1). The titles and abstracts of the remaining articles were reviewed, and 9 that were judged to not have met the inclusion criteria were excluded. Finally, 7 articles were included in this review of the efficacy of boric acid in treating CSOM or CSOM bacteria in vitro. For reviewing the ototoxicity of boric acid, we found 4 articles that all met the inclusion criteria. Therefore, we included all 4 articles reporting on the ototoxicity of boric acid in this review.

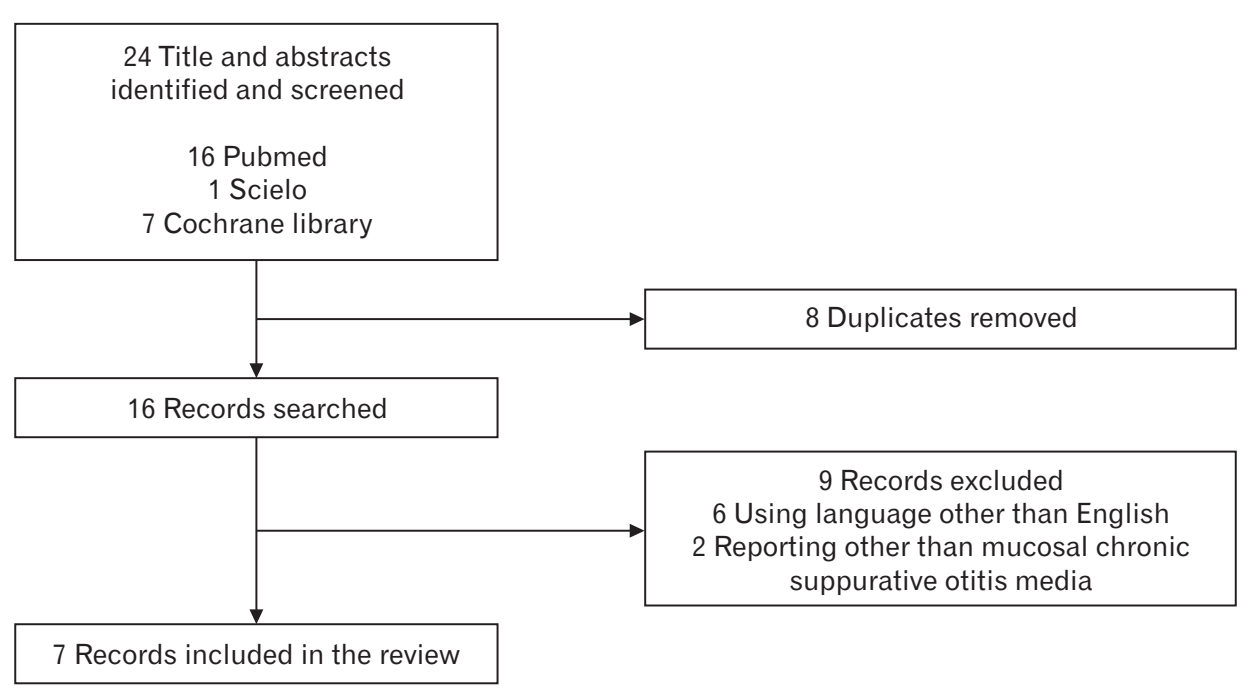

Figure 1. Study flow chart. 


\section{EFFECT OF AN ACIDIC ENVIRONMENT ON THE INFECTED SURFACE}

Chronic infection is usually caused by the presence of bacteria and bacterial products, such as endotoxins and metalloproteinases, which can disturb the host's resistance. Most pathogenic bacteria associated with human infections require a $\mathrm{pH}>6$, as their growth is inhibited in environments with lower $\mathrm{pH}$ values. Microbiological studies have proven that applying acid to the infected surface lowers the $\mathrm{pH}$ and makes the environment unsuitable for bacterial growth and multiplication. By lowering the $\mathrm{pH}$ of infected wounds, several mechanisms can be reduced, one of which is the activity of the protease enzyme produced by the bacteria, which reduces the formation and toxicity of their end products. ${ }^{14)}$

An acidic environment also influences the release of oxygen, which is the basic requirement for cell survival. The majority of the oxygen is required to produce oxygen radicals, which are the mainstay of immunity against bacterial infections. A low $\mathrm{pH}$ leads to the Bohr effect. Lowering the $\mathrm{pH}$ by 0.9 units produces a 5 -fold increase in the release of oxygen. The delivery of oxygen to damaged tissue depends on perfusion as well as diffusion. Good tissue oxygenation increases resistance to infection and promotes healing. Oxygen is also required for the synthesis of collagen and epithelialization. ${ }^{14)}$

Various acids have been proven to increase the effectiveness of topical antimicrobials. For example, the use of boric acid with vancomycin has been shown to be more effective than the use of boric acid or vancomycin alone in reducing the number of methicillin-resistant Staphylococcus aureus bacteria in a rat model of tibial osteomyelitis. ${ }^{15)}$

\section{BORIC ACID FOR CHRONIC SUPPURATIVE OTITIS MEDIA TREATMENT}

The first step in treating active tubotympanic CSOM is to render it inactive. Various studies have examined treatment options. An aural toilet with dry mopping alone or dry mopping with saline has been shown to be less effective than is a combination of antibiotics, antiseptics, or steroids. Further, topical agents are better than systemic agents. ${ }^{16,17)}$ However, there is no consensus among general physicians and otolaryngologists regarding the optimal management therapy for CSOM. The two principal aims of therapy are the eradication of infection and the closure of the tympanic perforation. The most commonly measured outcome of the eradication of infection is the disappearance of discharge after treatment. Many times, these patients first consult general physicians, for whom knowledge about the microorganism causing CSOM is essential for initiating therapy. Patients are referred to the otolaryngologist when the initial treatments have failed or surgery is needed to permanently close the tympanic perforation. Several therapeutic options have been recommended by the World Health Organization, including aural toilet and antimicrobial treatments such as oral antibiotics, topical antibiotics, parenteral antibiotics, and topical antiseptics. The WHO suggested that topical antibiotics were better than aural toilet alone and systemic antibiotics. Moreover, topical antiseptics may be as effective as topical antibiotics. The commonly used topical antiseptics include boric acid, zinc peroxide powder, iodine powder, dilute acetic acid drops, Burow's solution, and Spirit eardrops BPC containing industrial methylated spirit and water. ${ }^{18,19)}$

Topical antibiotics that are not potentially ototoxic are the first line of therapy. However, they are expensive and require patient compliance in administration. Moreover, the extensive use of topical antibiotics can lead to resistance. ${ }^{1,16)}$ The topical antibiotics used to treat CSOM are framycetin, gramicidin, ciprofloxacin, tobramycin, gentamicin, and chloramphenicol. Among these topical antibiotics, topical fluoroquinolones are considered more effective than are the other types of topical antibiotics. ${ }^{18)}$ Topical fluoroquinolones also represent a safer alternative for treating otorrhea. Meanwhile, aminoglycosidecontaining otic preparations have been reported to cause ototoxicity if the tympanic membrane is not intact. ${ }^{20)}$

Ofloxacin and ciprofloxacin are fluoroquinolones showing activity against most gram-negative and gram-positive microorganisms causing CSOM. Fluoroquinolones act by inhibiting the DNA gyrase enzyme that is essential for DNA replication, repair, deactivation, and transcription. The majority of the isolated Pseudomonas aeruginosa strain are still sensitive to ciprofloxacin. However, the overuse of topical antibiotic ear drops is leading to resistance. ${ }^{21)}$ Three mechanisms of resistance to quinolones are currently recognized: mutations that alter the drug targets, mutations that reduce drug accumulation, and plasmids that protect cells from the lethal effects of quinolones. Quinolone-resistant mutants of $P$. aeruginosa fall into two classes: those resulting from target-site mutations in DNA gyrase, and those resulting from efflux mutations. ${ }^{22,23)}$

Boric acid powder is a significantly less expensive alternative to topical antibiotics. Boric acid first used as an antiseptic in 1875. Later, in 1969, Porter et al. ${ }^{24)}$ demonstrated the advantages of boric acid in preserving urine while in transit. Boric acid was claimed to have a bacteriostatic effect that prevented the bacteria present from changing significantly for up to 48 hours at room temperature; however, other cellular elements remained substantially intact. ${ }^{25,26)}$ Meers and Chow ${ }^{26)}$ also reported the bacteriostatic and bactericidal effects of boric acid on $P$. aeruginosa, Acinetobacter calcoaceticus, and group B streptococci at a concentration of 10 or $20 \mathrm{~g} / \mathrm{L}$.

Boric acid is derived from boron, which has a high affinity for ribose, a constituent of several essential biological molecules, including ATP (adenosine triphosphate), NADH (nicotinamide adenine dinucleotide), NADPH (nicotinamide adenine dinucleotide phosphate), and RNA. Excessive amounts of boron can impair protein synthesis and the activities of serine-protease, $\beta$-lactamase, and amino-acyl tRNA synthetase, which are enzymes in the microorganism that cause mitochondrial dysfunction and disrupt cell division and development. Increased boron concentration may also affect quorum sensing, which is a vital mechanism in microorganisms. Boron is required for the maintenance of the structure and function of cell membranes, and excess boron impairs membrane function, integrity, conformation, and 
transport capacity. ${ }^{12,27)}$

The effect of boric acid on biofilms has gained attention in recent years, as it has been found to inhibit biofilm formation in some bacterial strain cultures. Biofilms are microbial communities that are formed by microorganism capable of sensing and attaching to surfaces. Biofilm bacteria respond to some physical and chemical factors. In particular, biofilm bacteria are up to 1,000-fold more resistant to antimicrobial agents than are free bacterial forms. ${ }^{12,13)}$ Therefore, biofilms are one of the causes of many recurrent and chronic infections. Some studies have reported the presence of biofilms in tissue samples from the middle ear of patients with CSOM. ${ }^{11,28)}$

\section{EFFECT OF BORIC ACID ON BIOFILMS}

Biofilms are microbial communities of surface-attached cells embedded in a self-produced extracellular matrix. Biofilms make bacteria more resistant to antimicrobial agents. Biofilm-associated bacterial and fungal microorganisms have been recognized to play a role in multiple infectious diseases, especially in their persistence and recurrence. The use of boric acid has become a highlight in the treatment of bacterial vaginosis (BV) and vulvovaginal candidiasis (VVC). Intravaginal boric acid has an advantage in treating recurrent BV and VVC, perhaps by influencing the biofilm and enhancing the antibacterial effect of conventional antimicrobial therapy. Boric acid may exert its effect in BV through the decimation of the vaginal biofilm or changes in the acidity of the vagina; moreover, its fungistatic activity may be attributed to fungal cell wall penetration or fungal cell membrane disruption. $^{29,30)}$

Zan et al. ${ }^{13)}$ conducted a study evaluating the antibacterial effect of different concentrations of boric acid on Enterococcus faecalis biofilms in human root canals. He found that increased concentrations of boric acid showed a strong relation to its antibacterial effect. In a comparison among $2 \%, 4 \%$, and $6 \%$ concentrations of boric acid, the $6 \%$ concentration had the highest antibacterial effect, reducing $69 \%$ of biofilms in cultures.

Although the exact mechanism underlying the antimicrobial effects of boric acid remains unclear, boric acid has been found to have bacteriostatic, bactericidal, and antibiofilm effects. Therefore, boric acid alone or in combination with another antibiotic can be the treatment of choice for recurrent or chronic infection. ${ }^{13,15,26)}$

\section{EFFICACY OF BORIC ACID IN PATIENTS WITH CHRONIC SUPPURATIVE OTITIS MEDIA}

Studies on the efficacy of boric acid in CSOM have yielded varying results. An in vitro study showed that $4 \%$ boric acid was not as effective as $100 \%$ and $50 \%$ Burow's solution, $2 \%$ acetic acid, or vinegar in water (1:1) in inactivating several strains of bacteria. The tested bacteria were isolated during antibiotic susceptibility testing of patients with CSOM. Although boric acid still has an antibacterial effect, the time required to inactivate $90 \%$ of the microorganism population was the highest for boric acid. ${ }^{31)}$ Macfadyen et al. ${ }^{32)}$ also found that boric acid was less effective than ciprofloxacin drops in treating ear discharge in patients with CSOM. This research showed similar result to the previous one. Eason et al., ${ }^{33)}$ in 1986, reported that boric acid produced no additional benefit over aural toilet alone. In these studies, boric acid was used at relatively low concentrations ( $2 \%$ ). Therefore, we assumed that the concentration of boric acid is related to its antimicrobial effect (Table 1). A study evaluating the bactericidal effect of boric acid also found that at $0.5 \%, 0.75 \%$, and $1 \%$ concentrations, boric acid does not have any bactericidal effect. ${ }^{34}$

Several studies have found that boric acid was effective in treating CSOM. Minja et al. ${ }^{17)}$ reported that boric acid had a more significant effect than did dry mopping alone in patients with CSOM, without any hearing impairment. They also found that adding oral amoxicillin had no significant effect on the treatment outcome. A study by Moshi et al. ${ }^{35)}$ evaluated pus swab specimen cultures from 150 patients with chronic otitis media, and found that $3 \%$ boric acid in a spirit ear drop was effective in inhibiting $P$. aeruginosa growth. This research also determined the shelf life of $3 \%$ boric acid in the spirit ear drop and showed that this solution was effective even after it had been stored at room temperature for 6 weeks. Loock ${ }^{16)}$ applied boric acid powder directly to the external ear canal (EAC) after the EAC was flushed with saline to treat CSOM, and had very satisfying results. Boric acid powder was superior to $1 \%$ acetic acid and ciprofloxacin drops. We assumed that the boric acid powder applied directly to the EAC had a higher concentration than did $2 \%$ or $4 \%$ boric acid with distilled water or alcohol. A high concentration of boric acid can be the key to successful treatment (Table 1).

We also found one case report describing the use of boric acid for treating nontuberculous mycobacterial infection. The patient had a poor response after being administered antibiotics for 7 months. He continued to show signs of right-sided CSOM. His middle ear cultures remained positive. ${ }^{36)}$ The patient received boric acid in powder form instilled into both ears weekly for 1 month, and monthly thereafter for a total of 3 months. After 1 month of topical treatment, the patient showed almost complete resolution of otorrhea without any side effects. This case report shows the potency of boric acid powder (Table $1)^{36)}$

\section{OTOTOXIC EFFECT OF BORIC ACID}

Ototoxicity refers to the injury to inner ear structures caused by the administration of medications or chemicals. This toxicity to the inner ear structures could be related to the cochlea, vestibule, or both. ${ }^{37)}$ Some animal studies have investigated the ototoxic potential of boric acid. ${ }^{38)}$

In a study by Minja et al., ${ }^{17)}$ a boric acid solution prepared with $70 \%$ alcohol was used in children diagnosed with suppurative otitis media. They reported that the boric acid solution prepared with $70 \%$ alcohol was effective in treating these patients. They did not confirm the risk of sensorineural hearing loss by performing hearing threshold examinations. They found that the hearing thresholds remained the same in 


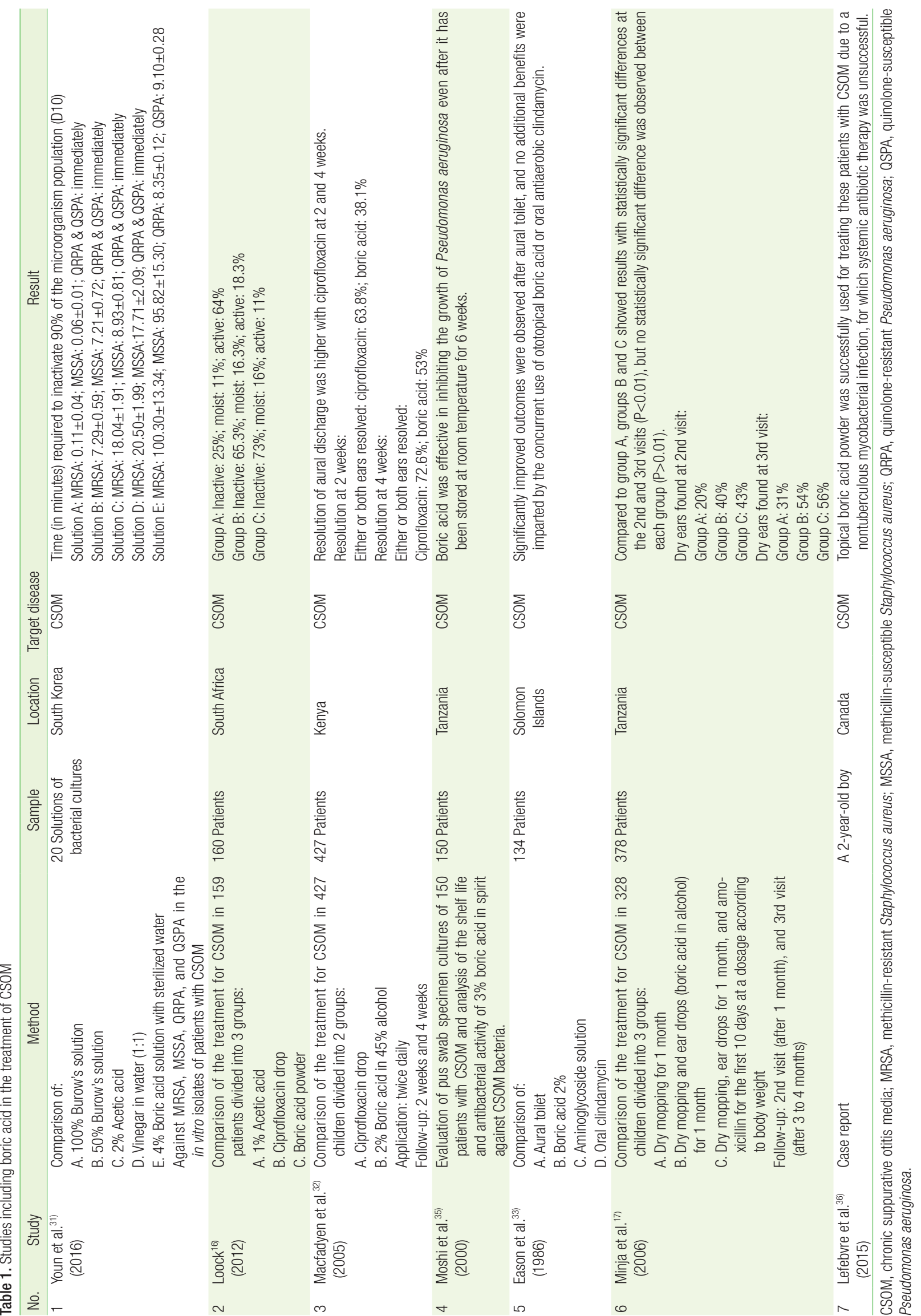


some patients before and after treatment, and the thresholds improved after treatment in other patients.

We found some studies that evaluated the ototoxic effect of topical boric acid in normal animal cochlea. All of the studies involved perforation of the tympanic membrane under the microscope by using a pick. A gelfoam was inserted through the perforation in alignment with the round window, where boric acid was applied twice a day. ${ }^{9,37,38)}$

In the first research, Ozturkcan et al. ${ }^{37)}$ reported their results of the comparison of a $4 \%$ boric acid solution prepared with $70 \%$ alcohol group, a saline group, and a $4 \%$ boric acid solution prepared with distilled water group. The solutions were administered to the ear at a dose of $0.1 \mathrm{~mL}$ (two drops) for 10 days. On the 15th day, the auditory brainstem response (ABR) test was performed. A statistically significant toxic effect was detected in the $4 \%$ boric acid solution prepared with $70 \%$ alcohol group. No statistically significant difference was found in a comparison of the saline and $4 \%$ boric acid solution prepared with distilled water groups $(\mathrm{P}=0.653)$. A study by Aktas et al. ${ }^{9}$ also found a significant difference in ABR test results between the preadministration and postadministration of $4 \%$ boric acid with $60 \%$ alcohol $(\mathrm{P}<0.001)$ and with $40 \%$ alcohol $(\mathrm{P}=0.007)$ for 10 days. The ABR test was conducted 5 days after the 10-day administration period (Table 2). The latest research by Salihoglu et al. ${ }^{39)}$ showed an interesting method of boric acid application. They divided the animals into two groups and applied boric acid powder directly to the middle ear cavity through a tympanic perforation made using a surgical microscope. Inner ear function was detected using distortion product otoacoustic emission (DPOAE) at 2,000, 3,000, 4,000, 6,000, and 8,000 Hz, measured before and after perforation. After boric acid application, DPOAE and histological changes were evaluated on the 3rd day in group A and the 40th day in group B. Boric acid powder was applied

Table 2. Studies including the ototoxic effect of boric acid

\begin{tabular}{|c|c|c|c|c|c|}
\hline No. & Study & Method & Samples & Location & Result \\
\hline 1 & $\begin{array}{l}\text { Ozturkcan et al. } .^{37)} \\
\text { (2009) }\end{array}$ & $\begin{array}{l}\text { Comparison of ototoxicity by measuring ABR test } \\
\text { results between } 4 \text { groups of animals with different } \\
\text { middle ear solutions. } \\
\text { Group A: } 4 \% \text { boric acid solution prepared with } 70 \% \\
\text { alcohol } \\
\text { Group B: } 4 \% \text { boric acid solution prepared with } \\
\text { distilled water } \\
\text { Group C: gentamicin solution ( } 40 \mathrm{mg} / \mathrm{mL} \text { ) (ototoxic } \\
\text { group) } \\
\text { Group D: saline solution (control group) }\end{array}$ & $\begin{array}{l}28 \text { Young albino } \\
\text { guinea pigs }\end{array}$ & Turkey & $\begin{array}{l}\text { Statistical analysis: } \\
\text { Saline/gentamicin: } P=0.003 \\
\text { Saline/ } 4 \% \text { boric acid solution prepared with distilled } \\
\text { water: } P=0.653 \\
\text { Saline/ } 4 \% \text { boric acid solution prepared with } 70 \% \text { alcohol: } \\
P=0.02 \\
4 \% \text { boric acid solution prepared with distilled water } / 4 \% \\
\text { boric acid solution prepared with } 70 \% \text { alcohol: } \\
P=0.000\end{array}$ \\
\hline 2 & $\begin{array}{l}\text { Ozdemir et al. }{ }^{38)} \\
(2013)\end{array}$ & $\begin{array}{l}\text { Comparison of ototoxicity by measuring DPOAE } \\
\text { amplitudes between } 5 \text { groups of animals with } \\
\text { different middle ear solutions: } \\
\text { Group A: } 0.1 \mathrm{~mL} \text { of oxiconazole-containing solution } \\
\text { drops } \\
\text { Group B: } 4 \% \text { boric acid in alcohol solution drops } \\
\text { Group C: gentamicin solution ( } 40 \mathrm{mg} / \mathrm{mL} \text { ) (ototoxic } \\
\text { control) } \\
\text { Group D: saline solution } \\
\text { Group E: followed up without any medication }\end{array}$ & $\begin{array}{l}50 \text { Adult Wistar } \\
\text { albino rats }\end{array}$ & Turkey & $\begin{array}{l}\text { No significant difference between animals in groups } A, B \text {, } \\
D \text {, and } E\end{array}$ \\
\hline 3 & $\begin{array}{l}\text { Aktas et al.9) } \\
(2013)\end{array}$ & $\begin{array}{l}\text { Comparison of ototoxicity by measuring ABR test } \\
\text { results between } 4 \text { groups of animals with different } \\
\text { middle ear solutions: } \\
\text { Group A: solution of } 4 \% \text { boric acid prepared with } \\
60 \% \text { alcohol } \\
\text { Group B: solution of } 4 \% \text { boric acid prepared with } \\
40 \% \text { alcohol } \\
\text { Group C: gentamicin ( } 40 \mathrm{mg} / \mathrm{mL} \text { ) as positive control } \\
\text { Group D: saline (negative control) }\end{array}$ & $\begin{array}{l}28 \text { Young albino } \\
\text { guinea pigs }\end{array}$ & Turkey & $\begin{array}{l}\text { Preadministration and postadministration thresholds } \\
\text { differed significantly in group } A(P<0.001) \text { and group } B \\
(P=0.007) \text {. } \\
\text { The degrees of hearing loss occurring as a result of the } \\
\text { administration of } 4 \% \text { boric acid solutions prepared with } \\
60 \% \text { and } 40 \% \text { alcohol differed significantly ( } P<0.001) \text {. }\end{array}$ \\
\hline 4 & $\begin{array}{l}\text { Salihoglu et al. }{ }^{39)} \\
(2017)\end{array}$ & $\begin{array}{l}\text { Comparison of ototoxicity by measuring DPOAE } \\
\text { results between } 2 \text { groups of animals. } \\
\text { Group A: DPOAE was measured before and after the } \\
\text { perforation was made. DPOAE and histological } \\
\text { changes were evaluated } 3 \text { days after the } \\
\text { application of } 35 \text { mg boric acid. } \\
\text { Group B: DPOAE was measured before and after the } \\
\text { perforation was made. DPOAE and histological } \\
\text { changes were evaluated } 40 \text { days after the } \\
\text { application of } 35 \text { mg boric acid. }\end{array}$ & $\begin{array}{l}20 \text { Wistar albino } \\
\text { rats }\end{array}$ & Turkey & $\begin{array}{l}\text { No significant differences were found at any of the } \\
\text { DPOAE frequencies. Mild inflammation of the middle } \\
\text { ear mucosa was found in groups A and B, which } \\
\text { resolved over time. }\end{array}$ \\
\hline
\end{tabular}

ABR, auditory brainstem response; DPOAE, distortion product otoacoustic emission. 
directly into the middle ear, considering the powder would have the highest concentration. They found no significant changes in DPOAE and only mild inflammation of the middle ear mucosa, which resolved over time.

The other study by Ozdemir et al. ${ }^{38)}$ yielded the opposite result. They found no significant difference between the $4 \%$ boric acid in alcohol group and saline groups, as well as between the $4 \%$ boric acid in alcohol group and no treatment group. The effects of solutions on the animals were measured by using DPOAE amplitudes at 2,000, 2,800, $4,000,6,000$, and 8,000 Hz. Pretreatment and posttreatment measurements were performed at an interval of 15 days. They detected a minimal decrease in DPOAE amplitudes in the posttreatment frequencies, but this decrease was not statistically significant (Table 2).

Alcohol has been found ototoxic in animal studies. Therefore, it would be a lot safer, especially in patients with a perforated tympanic membrane or an open mastoid cavity, to use boric acid in distilled water solution instead of boric acid in alcohol. ${ }^{38,40)}$

\section{CONCLUSION}

Several studies have evaluated the efficacy of boric acid as a treatment for CSOM, but these have yielded mixed results. In our opinion, boric acid is relatively effective in treating CSOM, especially when used at high concentrations. It can be applied alone or in combination with antibiotics, but no study has investigated its specific application as an ototopical agent. The use of boric acid is expected to prevent the extensive use of antibiotics that can lead to microbial resistance; however, the use of boric acid as a first-line therapy needs further research. Animal studies have shown that the application of $4 \%$ boric acid in distilled water for 10 days was safer than the application of boric acid in an alcohol preparation for the same duration. The direct application of boric acid powder was found relatively safe, suggesting that boric acid at a high concentration was safe and did not affect inner ear function. Nevertheless, the ototoxicity of boric acid solutions at concentrations higher than $4 \%$ needs further evaluation, considering this is the more applicable regimen as an ototopical agent.

\section{CONFLICT OF INTEREST}

No potential conflict of interest relevant to this article was reported.

\section{REFERENCES}

1. Mittal R, Lisi CV, Gerring R, Mittal J, Mathee K, Narasimhan G, et al. Current concepts in the pathogenesis and treatment of chronic suppurative otitis media. J Med Microbiol 2015;64:1103-16.

2. Anggraeni R, Hartanto WW, Djelantik B, Ghanie A, Utama DS, Setiawan EP, et al. Otitis media in indonesian urban and rural school children. Pediatr Infect Dis J 2014;33:1010-5.

3. Gorgulu O, Ozelci M, Ozdemir S, Yasar M, Olgun MK, Arikan OK. The role of allergy in the pathogenesis of chronic suppurative otitis media. J Int Adv Otology 2012;8:276-80.
4. Yorgancılar E, Yildirim M, Gun R, Bakir S, Tekin R, Gocmez C, et al. Complications of chronic suppurative otitis media: a retrospective review. Eur Arch Otorhinolaryngol 2013;270:69-76.

5. Chowdhury MA, Alauddin M. Comparative study between tubotympanic and atticoantral types of chronic suppurative otitis media. Bangladesh Med Res Counc Bull 2002;28:36-44.

6. Islam MR, Taous A, Hossain MM, Ekramuddaula AF, Islam MS. Comparative study of tubotympanic and atticoantral variety of chronic suppurative otitis media. Bangladesh J Otorhinolaryngol 2010;16:1139.

7. Prakash M, Lakshmi K, Anuradha S, Swathi GN. Bacteriological profile and their antibiotic susceptibility pattern of cases of chronic suppurative otitis media. Asian J Pharm Clin Res 2013;6:210-2.

8. Sugamura M, Yamano T, Higuchi H, Takase H, Yoshimura H, Nakagawa T, et al. Ototoxicity of Burow solution on the guinea pig cochlea. Am J Otolaryngol 2012;33:595-9.

9. Aktas S, Basoglu MS, Aslan H, Ilknur AE, Dundar R, Katilmis H, et al. Hearing loss effects of administering boric alcohol solution prepared with alcohol in various degrees on guinea pigs (an experimental study). Int J Pediatr Otorhinolaryngol 2013;77:1465-8.

10. Bjarnsholt T, Alhede M, Jensen PO, Nielsen AK, Johansen HK, Homoe $\mathrm{P}$, et al. Antibiofilm properties of acetic acid. Adv Wound Care (New Rochelle) 2015;4:363-72.

11. Lee MR, Pawlowski KS, Luong A, Furze AD, Roland PS. Biofilm presence in humans with chronic suppurative otitis media. Otolaryngol Head Neck Surg 2009;141:567-71.

12. Sayin Z, Ucan US, Sakmanoglu A. Antibacterial and antibiofilm effects of boron on different bacteria. Biol Trace Elem Res 2016;173:241-6.

13. Zan R, Hubbezoglu I, Ozdemir AK, Tunc T, Sumer Z, Alici O. Antibacterial effect of different concentration of boric acid against enterococcus faecalis biofilms in root canal. Marmara Dent J 2013;1:76-80.

14. Nagoba BS, Suryawanshi NM, Wadher B, Selkar S. Acidic environment and wound healing: a review. Wounds 2015;27:5-11.

15. Guzel Y, Golge UH, Goksel F, Vural A, Akcay M, Elmas S, et al. The efficacy of boric acid used to treat experimental osteomyelitis caused by Methicillin-resistant Staphylococcus aureus: an in vivo study. Biol Trace Elem Res 2016;173:384-9.

16. Loock JW. A randomised controlled trial of active chronic otitis media comparing courses of eardrops versus one-off topical treatments suitable for primary, secondary and tertiary healthcare settings. Clin Otolaryngol 2012;37:261-70.

17. Minja BM, Moshi NH, Ingvarsson L, Bastos I, Grenner J. Chronic suppurative otitis media in Tanzanian school children and its effects on hearing. East Afr Med J 2006;83:322-5.

18. Acuin J. Chronic suppurative otitis media: burden of illness and management options [Internet]. Geneva: World Health Organization; 2004 [cited 2010 Jan 28]. Available from: http://www.who.int/pbd/deafness/activities/hearing_care/otitis_media.pdf.

19. Verhoeff M, van der Veen EL, Rovers MM, Sanders EA, Schilder AG. Chronic suppurative otitis media: a review. Int J Pediatr Otorhinolaryngol 2006;70:1-12.

20. Bradley JS, Jackson MA; Committee on Infectious Diseases; American Academy of Pediatrics. The use of systemic and topical fluoroquinolones. Pediatrics 2011;128:e1034-45.

21. Daniel SJ. Topical treatment of chronic suppurative otitis media. Curr 
Infect Dis Rep 2012;14:121-7.

22. Jacoby GA. Mechanisms of resistance to quinolones. Clin Infect Dis 2005;41 Suppl 2:S120-6.

23. Hancock RE. Resistance mechanisms in Pseudomonas aeruginosa and other nonfermentative gram-negative bacteria. Clin Infect Dis 1998;27 Suppl 1:S93-9.

24. Porter IA, Path MC, Brodie J, Path FC. Boric acid preservation of urine samples. Br Med J 1969;2:353-5.

25. Baker DH, Wilson RE. The lethality of boric acid in the treatment of burns. JAMA 1963;186:1169-70.

26. Meers PD, Chow CK. Bacteriostatic and bactericidal actions of boric acid against bacteria and fungi commonly found in urine. J Clin Pathol 1990;43:484-7.

27. Yilmaz MT. Minimum inhibitory and minimum bactericidal concentrations of boron compounds against several bacterial strains. Turk J Med Sci 2012;42(Sup 2):1423-9.

28. Homoe P, Bjarnsholt T, Wessman M, Sorensen HC, Johansen HK. Morphological evidence of biofilm formation in Greenlanders with chronic suppurative otitis media. Eur Arch Otorhinolaryngol 2009;266:1533-8.

29. Muzny CA, Schwebke JR. Biofilms: an underappreciated mechanism of treatment failure and recurrence in vaginal infections. Clin Infect Dis 2015;61:601-6.

30. Bradshaw CS, Brotman RM. Making inroads into improving treatment of bacterial vaginosis: striving for long-term cure. BMC Infect Dis 2015;15:292.

31. Youn CK, Jang SJ, Jo ER, Choi JA, Sim JH, Cho SI. Comparative antibacterial activity of topical antiseptic eardrops against methicillin-resistant Staphylococcus aureus and quinolone-resistant Pseudomonas aeruginosa. Int J Pediatr Otorhinolaryngol 2016;85:80-3.

32. Macfadyen C, Gamble C, Garner P, Macharia I, Mackenzie I, Mugwe P, et al. Topical quinolone vs. antiseptic for treating chronic suppurative otitis media: a randomized controlled trial. Trop Med Int Health 2005;10:190-7.

33. Eason RJ, Harding E, Nicholson R, Nicholson D, Pada J, Gathercole J. Chronic suppurative otitis media in the Solomon Islands: a prospective, microbiological, audiometric and therapeutic survey. N Z Med J 1986;99:812-5.

34. Kumara DU, Fernando SS, Kottahachchi J, Dissanayake DM, Athukorala GI, Chandrasiri NS, et al. Evaluation of bactericidal effect of three antiseptics on bacteria isolated from wounds. J Wound Care 2015;24:5-10.

35. Moshi NH, Minja BM, Ole-Lengine L, Mwakagile DS. Bacteriology of chronic otitis media in Dar es Salaam, Tanzania. East Afr Med J 2000;77:20-2.

36. Lefebvre MA, Quach C, Daniel SJ. Chronic suppurative otitis media due to nontuberculous mycobacteria: a case of successful treatment with topical boric acid. Int J Pediatr Otorhinolaryngol 2015;79:1158-60.

37. Ozturkcan S, Dundar R, Katilmis H, Ilknur AE, Aktas S, Haciomeroglu $\mathrm{S}$. The ototoxic effect of boric acid solutions applied into the middle ear of guinea pigs. Eur Arch Otorhinolaryngol 2009;266:663-7.

38. Ozdemir S, Tuncer U, Tarkan O, Akar F, Surmelioglu O. Effects of topical oxiconazole and boric acid in alcohol solutions to rat inner ears. Otolaryngol Head Neck Surg 2013;148:1023-7.

39. Salihoglu M, Dogru S, Cesmeci E, Caliskan H, Kurt O, Kucukodaci Z, Gungor A. Ototoxicity of boric acid powder in a rat animal model. Braz J Otorhinolaryngol 2017 Apr 22 [In Press]. https://doi.org/10.1016/ j.bjorl.2017.03.010.

40. Perez R, Freeman S, Sohmer H, Sichel JY. Vestibular and cochlear ototoxicity of topical antiseptics assessed by evoked potentials. Laryngoscope 2000;110:1522-7. 